\title{
Hitting Retributivism Where It Hurts
}

\author{
Nathan Hanna ${ }^{1}$ (i)
}

(C) Springer Science+Business Media B.V., part of Springer Nature 2018

\begin{abstract}
Many philosophers think that, when someone deserves something, it's intrinsically good that she get it or there's a non-instrumental reason to give it to her. Retributivists who try to justify punishment by appealing to claims about what people deserve typically assume this view or views that entail it. In this paper, I present evidence that many people have intuitions that are inconsistent with this view. And I argue that this poses a serious challenge to retributivist arguments that appeal to desert.
\end{abstract}

\section{Keywords Punishment $\cdot$ Retributivism $\cdot$ Desert $\cdot$ Normativity}

Consider this view:

When someone deserves something, it's intrinsically good that she get it or there's a non-instrumental reason to give it to her.

Serena Olsaretti says that such a view is one of the "few basic points of substantive agreement among desert theorists" (2003: 4). Call it the standard view then. ${ }^{1}$ Many

\footnotetext{
1 In Hanna (2013: 42), I cite nearly a dozen philosophers who endorse the standard view or views that entail it. Olsaretti puts the view a bit differently. Here's her version of the value clause: it's intrinsically better if the person gets what she deserves. And here's her version of the reasons clause: the person ought to get what she deserves, other things equal. I'll discuss Olsaretti's take on the value clause later. My take on the reasons clause is meant to accommodate a broader range of views, e.g., Feinberg's (1970: 60) and Husak's (2013: 11-13). I've put the view disjunctively because some desert theorists doubt that all claims about what people deserve have both of the stated implications. See Husak (2013: 11-12), Olsaretti (2003: 8), and Sher (1987: 6-8). Cf. Feldman and Skow (2015: Sect. 5).
}

Nathan Hanna

nth34@drexel.edu

1 Drexel University, MacAlister Hall, Room 5044, 3250-60 Chestnut Street, Philadelphia, PA 19104, USA 
of those who accept it just assume it. But it should be examined more carefully. Desert is central to a number of philosophical debates, particularly debates about the morality of punishment. ${ }^{2}$ Many retributivists try to justify punishment by assuming the standard view or views that entail it and appealing to intuitions about what people deserve. In this paper, I'll present empirical evidence that there are widespread intuitions that are inconsistent with the standard view. I'll use this evidence to argue that retributivists who defend punishment by appealing to desert must do more to defend their assumptions about the normativity of desert.

Here's an outline of my paper. In Sect. 1, I'll sketch a representative retributivist argument that appeals to the standard view. I'll also discuss a proposed counterexample to that view from my earlier work. In Sect. 2, I'll present the results of survey research that I conducted to investigate people's intuitions about the counterexample. My results suggest that many people have intuitions that are inconsistent with the standard view and with an important variant of it. In Sect. 3, I'll argue that my results pose an important challenge to retributivist arguments that appeal to desert. I'll consider several responses to my challenge-e.g., that such arguments don't have to assume the standard view_and I'll raise doubts about them.

\section{Retributivism and the Standard View}

In this section, I'll sketch a representative retributivist argument that appeals to desert. I'll explain the standard view's role in the argument. I'll show that some prominent retributivists endorse such arguments. And I'll summarize my earlier challenge to these arguments and their appeal to the standard view.

Here's a representative retributivist argument that appeals to desert. It starts by assuming the standard view.

1. When someone deserves something, it's intrinsically good that she get it or there's a non-instrumental reason to give it to her.

Next, the argument appeals to a claim about what certain people deserve.

2. Wrongdoers deserve things that are bad for them, e.g., suffering or punishment.

By wrongdoing I mean whatever retributivists take the relevant desert bases to be. Obvious candidates include culpably and unjustly harming others. ${ }^{3}$ From 1 and 2 , the argument draws a normative conclusion.

3. So, it's intrinsically good when wrongdoers get these things or there are noninstrumental reasons to give them these things.

\footnotetext{
${ }^{2}$ Desert also features significantly in debates about distributive justice. For recent discussions, see Feldman (2016), Feldman and Skow (2015), and Freiman and Nichols (2011).

${ }^{3}$ Cf. Alexander and Ferzan (2009: 6) and Berman (2008: 269). On the concept of a "desert base", see Feinberg (1970) and Feldman and Skow (2015: S. 3).
} 
Retributivists disagree with one another about how much intrinsic value there is in wrongdoers getting what they deserve and about the strength of the non-instrumental reasons to give them what they deserve. As a result, retributivists disagree about what it takes to get from claims like 2 to further conclusion about the justifiability of punishment. ${ }^{4}$ These disagreements won't matter for my purposes, though. What matters is how arguments like the one above use the standard view to defend claims like 3. I'll explain.

Claims like 3 are very controversial. Retributivists take such claims to be intuitively compelling. But anti-retributivists have long challenged the reliability of intuitions for such claims. ${ }^{5}$ Retributivists try to counter these challenges by giving independent support for the claims. The argument above illustrates a common way that they do this: by appealing to desert. Arguments like this are attractive for at least two reasons. First, claims about what people deserve seem morally important and there's an intuitively attractive, widely accepted account of their importance: the standard view. The standard view gives retributivists a principled way to draw normative conclusions like 3 from claims about what wrongdoers deserve. Second, claims about what people deserve are ubiquitous. It seems that people can deserve all sorts of things-some good for them, some bad for them-on the basis of facts about them like their free acts. Retributivists defend claims like 2 by saying that people have especially strong and widespread intuitions for it or claims like it, intuitions that can be elicited by presenting people with cases of wrongdoing. If retributivists are right about this, claims like 2 have a degree of intuitive support comparable to that of other widely accepted claims about what people deserve.

Critics of these arguments largely focus on claims like 2. They argue that retributivists' claims about what wrongdoers deserve might be false. ${ }^{6}$ Few critics consider the possibility of objecting to claims like 1 . That is, few think to challenge retributivists' assumptions about the normativity of desert. I think that objections to these assumptions are worth exploring, whatever the merits of the objections to claims like 2. In the rest of this section, I'll show that prominent retributivists endorse arguments like the one above. Then I'll summarize part of my earlier challenge to the standard view.

Lawrence Davis begins his influential paper "They Deserve to Suffer" by asserting this: the claim that the guilty deserve to suffer entails that it's intrinsically good that they suffer (1972: 136). He then defends this value claim as follows.

\footnotetext{
${ }^{4}$ Compare Moore (1987: 180, 1993: 16) with Husak (2000: 997, 998, 2013: 12-17), for example.

${ }^{5}$ For recent discussions, see Hanna (2014), Tadros (2011: 73-87), and Wiegman (2017). For more references, see Boonin (2008: 93, n10).

${ }^{6}$ One of the most popular objections says that these claims mistakenly presuppose that we have free will. See Greene and Cohen (2004), Kelly (2009), Parfit (2011: 258-272), Pereboom (2013), Tadros (2011: 61-66), and Vilhauer (2009). Another objection says that claims like 2 are questionable either because our intuitions about what wrongdoers deserve are questionable or because our deontological intuitions in general are questionable. See Narveson (1974: 193), Greene (2008), and Wiegman (2017). Another objection says that claims like 2 misunderstand the relationship between desert bases and what people deserve. See Ezorsky (1972: xxiv-xxvi), and Tadros (2011: 68, 69, 73). Another objection says that claims like 2 are true only if wrongdoers know that they're doing something wrong and they rarely if ever know this. See Rosen (2002) and Zimmerman (1997, 2002).
} 
But is [the value claim] true? I suggest that the answer is "very likely" on the grounds (a) that there is no convincing argument against it, and (b) that inclination to believe it seems widespread among the people whose moral intuitions constitute the main data we have for settling questions of value (1972: 139).

In support of (b) he says this ${ }^{7}$ :

Imagine an old-style Hollywood Western in which the villain, presented as irremediably wicked to the core, meets an unpleasant end in some natural disaster. Do you not feel that he has gotten what he deserved, that what happened was altogether fitting? If so, then you share in the intuition that [the value claim is true] (1972: 140).

Davis's argument seems to have all the hallmarks of the argument sketched above. He seems to assume a view that entails the standard view: it's intrinsically good when people get what they deserve. ${ }^{8} \mathrm{He}$ appeals to intuitions about cases to defend the claim that the guilty deserve to suffer. And he concludes that it's intrinsically good when they suffer. He adds that anyone who accepts the desert claim and thinks that there are good reasons to promote intrinsic value is also committed to the claim that there are (non-instrumental) reasons to make the guilty suffer (1972: 138).

Prominent contemporary retributivists endorse Davis's reasoning. Here's Mitchell Berman:

Thirty-odd years ago, Lawrence Davis succinctly adjudged the proposition that there is intrinsic value in wrongdoers' suffering "very likely" [for the reasons quoted above]. Today's antiretributivists are no closer to mounting a convincing counterargument (beyond relitigating the hard determinist challenge), while the ranks of those expressing such a belief have swelled. We therefore seem entitled to conclude that [the value claim is true]. ${ }^{9}$ (2008: 271).

Berman also takes Davis to be assuming that it's intrinsically good when people get what they deserve. He endorses this assumption and the rest of Davis's argument in the paper just quoted. ${ }^{10}$ But in more recent work he tentatively proposes a

\footnotetext{
7 Davis's defense of (a) briefly considers just one objection to the value claim: that the intuitions for it have suspect origins (1972: 140). Moore (1987) addresses such objections at length.

${ }^{8}$ You might think that Davis is only assuming this: it's intrinsically good when the guilty get what they deserve (thanks to George Sher for this worry). I don't think that this is a good reading of Davis. And there are other retributivists who read him like I do (see below). But I won't defend my reading. Instead, at the end of the paper, I'll critically discuss versions of the retributivist argument that appeal to narrower claims like the one above.

9 I've simplified Berman's conclusion. See his paper (2008: 261-271) for details, which aren't relevant here.

10 The assumption is implicit. Berman confirms this in a later paper discussing Victor Tadros's work: "[Tadros] appears to believe that a claim that some agent, A, deserves $\mathrm{O}$ on account of B is equivalent (or nearly so) to the claim that, given B, A's getting $\mathrm{O}$ would be intrinsically valuable. That is, Tadros appears to reduce a claim about desert to a claim about intrinsic value. That too is a plausible and common view. (I have in past work assumed it myself)" (2013: 90; citing his 2008: 269). He explicitly says that this view and the other views about desert that he discusses are views about "desert generally, and not retributivist desert in particular" (ibid., 269).
} 
more nuanced view that combines this assumption with a claim about the relationship between desert, reasons, and justice (2013: 90-93). On this view, our reasons to give people what they deserve aren't just a matter of promoting value but of doing justice. As such, these reasons can be strong enough to oblige certain agents and institutions to give certain people what they deserve. ${ }^{11}$

Michael Moore endorses similar reasoning. Like Davis, he defends claims like 2 by appealing to intuitions about cases.

I take seriously the sorts of particular moral judgments that Kant-like thought experiments call forth in me and in most people I know: imagine an offender who does a serious wrong in a very culpable way (1993: 25).

He says that such cases "lead to a common judgment of deserved punishment" (ibid.). He then argues that there are strong reasons to give these offenders what they deserve, claiming that these reasons stem from the very nature of desert.

The retributive principle - that offenders should be punished because and only because they have culpably done wrong - is an instance of [a] more general principle of desert (1993: 33, emphasis added).

According to Moore, this principle-which applies generally, both to cases of positive and negative desert - says that claims about what people deserve entail claims about what ought to be done to them, other things equal (1993: 32-33). So, Moore's argument also seems to have all the elements of the argument sketched above. He appeals to intuitions about cases to defend claims about what offenders deserve. He seems to assume a view that entails the standard view. And he uses that view to draw conclusions about what ought to be done to offenders from claims about what they deserve.

This overview shows that prominent retributivists endorse arguments like the one sketched at the beginning of this section. While I've focused on just a few retributivists whose explicit reasoning most clearly matches the argument, I suspect that many retributivists who try to justify punishment by appealing to desert implicitly assume something like the standard view. ${ }^{12}$ It's hard to be sure about this, though, since few retributivists explicitly state their assumptions about desert's normativity (cf. Berman 2013: 90-91). Whatever the case may be, I'll show that retributivists must think more carefully about desert's normativity. I'll do this by showing that arguments like the one sketched above are questionable because of their reliance on the standard view. I'll also show that obvious ways of trying to improve these argumentse.g., by appealing to alternatives to the standard view-face important problems. To begin, I'll summarize my earlier challenge to these arguments and their reliance on the standard view.

\footnotetext{
11 Here's the view: "That A deserves $\mathrm{O}$ on account of $\mathrm{B}$ means (a) given $\mathrm{B}$, that $\mathrm{A}$ experience $\mathrm{O}$ (or that $\mathrm{O}$ obtain for $\mathrm{A}$ ) is better than that A not experience $\mathrm{O}$ (or that $\mathrm{O}$ not obtain for $\mathrm{A}$ ); and (b) if there is any agent or institution, $\mathrm{X}$, with responsibility over the relevant domain, then $\mathrm{X}$ has a duty of justice to cause O to obtain for A" (2013: 92).

12 Candidates include Alexander and Ferzan (2009), Fischer (2006, 2013), Hurka (2001), Husak (2000, 2013), Kagan (2003), Kershnar (2000, 2001), Kleinig (1973), and Zaibert (2006, 2017).
} 
In earlier work, I challenged these arguments by proposing counterexamples to the standard view. Here's one of my counterexamples (2013: 43-45). Suppose that someone recklessly performs a dangerous stunt to show off, knowingly risks her own well-being but no one else's, and suffers a minor injury as a result. I said that the following claims seem true: the reckless person deserved her injury, but it's intrinsically bad that she was injured and there was no non-instrumental reason to injure her. If these claims are true, the standard view is false and arguments that assume it are unsound. In defense of these claims, I said that desert claims like the claim that the reckless person deserved her injury are quite common (cf. Sher 1987: 41-42). And I speculated that many people would have intuitions about such cases that are inconsistent with the standard view. An important reply to my challenge grants that desert claims like this are common but says that they're best understood metaphorically, not literally (cf. Sher 1987: 10). In response, I said that there's a good reason to take such claims literally: they have explanatory value. The claim that the reckless person deserved her injury can explain why it's seemingly intrinsically worse for someone to suffer such an injury faultlessly. And it can explain why we seem to have more reason to do things like help the faultless person than the reckless one, other things equal.

I'm going to use this case to investigate whether people really do have intuitions that are inconsistent with the standard view. In my earlier work, I just speculated that many people would have such intuitions in response to my case. However plausible such speculation is, empirical evidence that such intuitions are widespread would pose an especially serious problem for retributivist arguments like the one sketched above. This is partly because of how much weight these arguments put on people's intuitions about desert. In the next section, I'll present the results of some surveys that I conducted to see what intuitions people have about cases like mine. The results suggest that many people have intuitions that are inconsistent with the standard view and with important variants of it. In the final section, I'll argue that these results pose an important challenge to retributivist arguments like the one sketched above. And I'll consider several ways of trying to meet the challenge.

\section{Three Studies}

I wanted to see if my counterexample really would elicit intuitions that are inconsistent with the standard view. I also wanted to see if people take desert claims like the one to which I appealed literally. And I wanted to see if people have intuitions that are inconsistent with an important variant of the standard view. So I conducted three studies to investigate.

\subsection{Study 1}

The first study tested whether my counterexample elicits intuitions that are inconsistent with the standard view. Via online surveys, I presented people with three cases: a control case, a version of my counterexample, and a case of violent wrongdoing. 
Control Connor is a college student. One night, he goes to a frat party. After hanging out for a while, he decides to call it a night and go home. Connor walks home, taking care to watch where he is going. Connor knows that he is behaving responsibly and taking no significant risks. On the walk home, he trips and sprains his ankle. Connor's spraining his ankle won't have any good or bad consequences (e.g., it won't teach him or anyone else a lesson, won't make him or anyone else more or less responsible, etc.).

Reckless Ricky is a college student. One night, he goes to a frat party. After hanging out for a while, he decides to perform a stunt to show off. Ricky jumps off of the roof of the frat house, taking care not to put anyone else at risk by jumping into the empty backyard. Ricky knows that he is running a significant risk of serious injury to himself for no good reason. As a result of his stunt, Ricky sprains his ankle. Ricky's spraining his ankle won't have any good or bad consequences (e.g., it won't teach him or anyone else a lesson, won't make him or anyone else more or less responsible, etc.).

Malicious Mal is a college student. One night, he goes to a frat party. After hanging out for a while, he decides to do something violent to show off. Mal walks up to another partygoer and knocks them down. Mal knows that he is harming another person for no good reason. Someone else quickly pushes Mal away, and Mal falls and sprains his ankle. Mal's spraining his ankle won't have any good or bad consequences (e.g., it won't teach him or anyone else a lesson, won't make him or anyone else more or less responsible, etc.).

Each case was accompanied by a question. To minimize the influence that participants' intuitions about the standard view itself would have on their intuition reports, I divided participants into three groups and asked each group questions about a single issue: desert, value, or reasons. I asked the desert group if the following three desert claims seem true or false.

- [Connor, Ricky, Mal] deserved to sprain his ankle.

I asked the value group if the following three intrinsic value claims seem true or false.

- It's good that [Connor, Ricky, Mal] sprained his ankle.

And I asked the reason group if the following three non-instrumental reason claims seem true or false.

- Someone who knew what [Connor, Ricky, Mal] did and who could have made him sprain his ankle would have had at least some reason to do so.

Note: these are intrinsic value claims and non-instrumental reason claims because the cases stipulated that the injuries wouldn't have any good or bad consequences. Participants recorded their answers on the following Likert scale. 


\begin{tabular}{|c|c|c|c|c|c|c|}
\hline 1 & 2 & 3 & 4 & 5 & 6 & 7 \\
\hline $\begin{array}{l}\text { Almost defi- } \\
\text { nitely false }\end{array}$ & $\begin{array}{l}\text { Probably } \\
\text { false }\end{array}$ & $\begin{array}{l}\text { More likely } \\
\text { false than } \\
\text { true }\end{array}$ & Neither & $\begin{array}{l}\text { More likely } \\
\text { true than } \\
\text { false }\end{array}$ & Probably true & $\begin{array}{c}\text { Almost defi- } \\
\text { nitely true }\end{array}$ \\
\hline
\end{tabular}

To minimize order effects, I randomized the order of the case/question pairs.

I recruited 125 participants via Amazon Mechanical Turk to take each survey, for a total of 375 participants. Participants weren't allowed to take more than one survey. I analyzed 325 participants' responses: 103 from the desert group, 104 from the value group, and 118 from the reason group. ${ }^{13}$ Table 1 reports the number of participants who gave each response. Figure 1 graphs the mean responses.

Here's a summary of the results. Desert group participants were statistically much more likely to report an intuition that Ricky and Mal deserved their injuries than Connor. A large majority reported intuitions that Connor didn't deserve his injury but that Ricky and Mal deserved theirs. The intuition reports from the value and reason groups exhibited a different pattern. There were still statistically significant differences between the intuitions reported about Ricky and Mal compared to Connor. But the intuitions about Ricky and Mal diverged. A large majority of the value group reported intuitions that it wasn't intrinsically good that Ricky was injured but that it was intrinsically good that Mal was injured. The intuition reports from the reason group exhibited the same pattern, with even fewer participants reporting an intuition that there was a reason to injure Ricky and even more reporting an intuition that there was a reason to injure Mal. ${ }^{14}$

These results are tentative evidence for the claim that there are widespread intuitions that are inconsistent with the standard view. At least three concerns might be raised about this study, however. First, I only asked participants about a single issue: desert, value, or reasons. If I'd asked them about all three, the vast majority might have reported sets of intuitions about Reckless that are consistent with the standard

\footnotetext{
${ }^{13}$ I excluded 50 participants' responses from analysis. These participants either gave incorrect responses to comprehension questions or their completion time was so fast that it suggested that they paid insufficient attention to the cases and questions. All participants were 18 years of age or older and located in the US. Demographic data for the analyzed responses is as follows. Desert group: $56.3 \%$ male, $43.7 \%$ female, median age 31 . Value group: $56.7 \%$ male, $43.3 \%$ female, median age 30 . Reasons group: $55.9 \%$ male, $44.1 \%$ female, median age 31.5 .

${ }^{14}$ I used Wilcoxon signed-rank tests to do the statistical analysis because the data was non-parametric. Here are the statistical details. Desert group 1.9\% reported an intuition that Connor deserved his injury $(\mathrm{Mdn}=1$, Mean $=1.51), 67 \%$ reported an intuition that Ricky did $(\mathrm{Mdn}=5$, Mean $=5.06, \mathrm{~T}=0$, $p<.001, \mathrm{r}=-.60)$, and $83.5 \%$ reported an intuition that Mal $\operatorname{did}(\mathrm{Mdn}=6, \mathrm{Mean}=5.94, \mathrm{~T}=0, p<.001$, $\mathrm{r}=-.60$ ). Value group $0 \%$ reported an intuition that it was intrinsically good that Connor was injured $(\mathrm{Mdn}=1$, Mean $=1.29), 29.8 \%$ reported an intuition that it was intrinsically good that Ricky was injured $(\mathrm{Mdn}=2$, Mean $=3.09, \mathrm{~T}=52, p<.001, \mathrm{r}=-.46)$, and $58.7 \%$ reported an intuition that it was intrinsically good that Mal was injured $(\mathrm{Mdn}=5$, Mean $=4.46, \mathrm{~T}=15, p<.001, \mathrm{r}=-.55)$. Reasons group $2.5 \%$ reported an intuition that there was a non-instrumental reason to injure Connor $(\operatorname{Mdn}=1$, Mean $=1.59$ ), $10.2 \%$ reported an intuition that there was such a reason to injure Ricky $(M d n=2$, Mean $=2.38, T=219$, $p<.001, \mathrm{r}=-.34)$, and $76.3 \%$ reported an intuition that there was such a reason to injure $\mathrm{Mal}(\mathrm{Mdn}=6$, Mean $=5.34, \mathrm{~T}=26, p<.001, \mathrm{r}=-.58$ ).
} 
Table 1 Responses: Study 1.

$D$ desert group, $V$ value group, $R$ reason group

\begin{tabular}{|c|c|c|c|c|c|c|c|c|c|}
\hline \multirow[t]{2}{*}{ Response } & \multicolumn{3}{|c|}{ Control } & \multicolumn{3}{|c|}{ Reckless } & \multicolumn{3}{|c|}{ Malicious } \\
\hline & $\mathrm{D}$ & $\mathrm{V}$ & $\mathrm{R}$ & $\mathrm{D}$ & $\mathrm{V}$ & $\mathrm{R}$ & $\mathrm{D}$ & $\mathrm{V}$ & $\mathrm{R}$ \\
\hline 1 & 74 & 82 & 84 & 3 & 40 & 48 & 1 & 22 & 4 \\
\hline 2 & 16 & 17 & 15 & 6 & 13 & 29 & 0 & 6 & 6 \\
\hline 3 & 5 & 2 & 7 & 7 & 9 & 10 & 3 & 3 & 8 \\
\hline 4 & 6 & 3 & 9 & 18 & 11 & 19 & 13 & 12 & 10 \\
\hline 5 & 1 & 0 & 2 & 20 & 10 & 5 & 14 & 15 & 24 \\
\hline 6 & 1 & 0 & 0 & 30 & 13 & 5 & 24 & 24 & 32 \\
\hline 7 & 0 & 0 & 1 & 19 & 8 & 2 & 48 & 22 & 34 \\
\hline
\end{tabular}

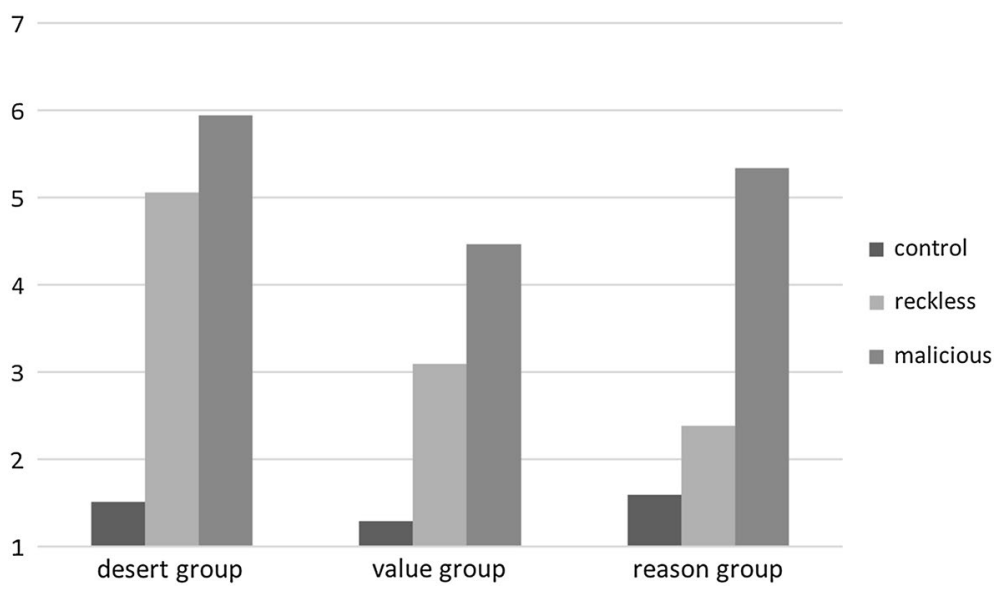

Fig. 1 Mean responses: Study 1

view. Second, participants who reported an intuition that Ricky deserved his injury may only have meant this metaphorically. My study didn't test whether they were being literal. Third, the intuitions that participants reported about Reckless and Malicious are consistent with important variants of the standard view. Retributivists might appeal to these variants to avoid any problems that my results might pose for them. Study 2 addresses the first and second concerns. Study 3 and the ensuing discussion address the third.

\subsection{Study 2}

I wanted to see if individual people have sets of intuitions about Reckless that are inconsistent with the standard view. I also wanted to see if people who report an intuition that Ricky deserved to sprain his ankle mean this literally. So I conducted a second study to investigate. 
Via an online survey, I presented people with Control and Reckless. I also added a stipulation to the cases: that the agents' injuries were equally severe and equally painful. I first asked participants if the following intrinsic value and non-instrumental reason claims seem true or false.

Bad and Worse $(B \& W)$ It's bad that Ricky sprained his ankle and it's even worse that Connor sprained his ankle.

None and More $(N \& M)$ There was no reason for anyone to make Connor or Ricky sprain their ankles, and someone who could only help one of them would have more reason to help Connor.

Recall, Connor was the Control agent, Ricky was the Reckless agent, and the cases stipulated that their injuries wouldn't have any good or bad consequences.

Following my earlier work, I surmised that people who intuit that Ricky deserved to sprain his ankle and who take this claim literally might use it to explain other things that seem true to them. If a participant reported an intuition for either of the above claims, then, I followed up by asking if desert explains why the claim is true. That is, I asked those who reported an intuition for $\mathrm{B} \& \mathrm{~W}$ if the following claim seems true or false.

Desert Explains Value (DEV) It's bad that Ricky sprained his ankle and it's even worse that Connor sprained his ankle because Ricky deserves his injury and Connor doesn't.

And I asked those who reported an intuition for N\&M if the following claim seems true or false.

Desert Explains Reasons (DER) Someone who could only help one of them with their injury would have more reason to help Connor because Ricky deserves his injury and Connor doesn't.

Participants recorded their answers on the same Likert scale as above $(1=$ almost definitely false, $7=$ almost definitely true).

I recruited 125 new participants via Amazon Mechanical Turk. People who took the previous surveys weren't allowed to take this one. I've reported 113 participants' responses. ${ }^{15}$ The results were as follows. Just over half of the participants reported intuitions for $\mathrm{B} \& \mathrm{~W}, \mathrm{~N} \& \mathrm{M}$, and either DEV or DER. And just under half reported intuitions for all of B\&W, N\&M, DEV, and DER. To be explicit: these participants reported intuitions that Ricky's being injured was intrinsically bad, that there was no non-instrumental reason to injure him, that he nevertheless deserved his injury, and that this explains differences in reasons and/or value between Reckless and Control.

\footnotetext{
15 I've excluded 12 participants' responses for the same reasons as in study 1. Demographic data for the analyzed responses are: $47.8 \%$ male, $52.2 \%$ female, median age 33 . All were 18 years of age or older and in the US.
} 
Table 2 Responses: Study 2

\begin{tabular}{lcccc}
\hline Response & B\&W & N\&M & DEV (/80) & DER (/78) \\
\hline 1 & 1 & 4 & 5 & 0 \\
2 & 3 & 8 & 2 & 1 \\
3 & 8 & 3 & 5 & 2 \\
4 & 21 & 20 & 6 & 4 \\
5 & 27 & 30 & 29 & 27 \\
6 & 27 & 29 & 18 & 28 \\
7 & 26 & 19 & 15 & 16 \\
\hline
\end{tabular}

Table 2 reports the number of participants who gave each response. The number of participants who answered the follow up questions are noted at the top of the relevant columns. $^{16}$

These results are further evidence that there are widespread intuitions that are inconsistent with the standard view. The results also suggest that many people take desert claims like the claim that Ricky deserved to sprain his ankle literally. Retributivists might be unimpressed by my results, though. They might think that they can easily avoid any problems that my results might pose for them by abandoning the standard view and appealing to variants of it instead. My third study focuses on one such variant.

\subsection{Study 3}

My results so far suggest that many people have intuitions about Reckless that are inconsistent with the standard view. Here's that view again.

When someone deserves something, it's intrinsically good that she get it or there's a non-instrumental reason to give it to her.

A common variant of this view modifies the value clause.

When someone deserves something, it's intrinsically better that she get it or there's a non-instrumental reason to give it to her. ${ }^{17}$

\footnotetext{
${ }^{16}$ Here's more data. 58 participants reported intuitions for B\&W, N\&M, and either DEV or DER (51.3\%). 52 reported intuitions for all of B\&W, N\&M, DEV, and DER (46\%). 80 participants reported an intuition for $\mathrm{B} \& \mathrm{~W}$ and 12 against $(71 \%$ and $10.6 \%$, respectively; $\mathrm{Mdn}=5$, Mean $=5.26)$. Of the 80 , 62 reported an intuition for DEV (77.5\% of the subsample, $54.9 \%$ of the entire sample) and 12 against (15\% of the subsample, $10.6 \%$ of the entire sample). 78 participants reported an intuition for N\&M and 15 against (69\% and $13.3 \%$, respectively; $M d n=6$, Mean $=5.01$ ). Of the 78, 71 reported an intuition for DER (91\% of the subsample, $62.8 \%$ of the entire sample) and 3 against (2.7\% of the entire sample, $3.8 \%$ of the subsample). 22 participants reported intuitions against one or both of B\&W and N\&M (19.5\%).

${ }^{17}$ Compare the formulations by Berman (2013: 92), Husak (2013: 11-12), and Olsaretti (2003: 4).
} 
Retributivists might say that the intuitions reported about Reckless are consistent with this variant. They might say that their arguments can be framed in terms of this variant. ${ }^{18}$ And they might conclude that intuitions about Reckless aren't really a problem for them. To assess this reply, I'll first spell out the implications that the variant view has when conjoined with relevant intuitions from studies 1 and 2 . Then I'll see if people find these implications intuitive.

To start, consider the variant view and the intuitions that most of the participants in studies 1 and 2 reported about Reckless.

- When someone deserves something, it's intrinsically better that she get it or there's a non-instrumental reason to give it to her.

- Ricky deserved to sprain his ankle.

- It's not intrinsically good that he sprained his ankle.

- There was no non-instrumental reason to make him sprain his ankle.

These claims jointly entail the following claim.

- It's intrinsically better that Ricky sprained his ankle but not intrinsically good. ${ }^{19}$

Retributivists might think that endorsing this claim and the variant view will let them plausibly argue for their position in a way that can accommodate intuitions about Reckless. I doubt that-it seems to me that it would have been intrinsically better had Ricky's stunt not injured him. I suspected that many people would agree. So I set out to test this suspicion.

Via an online survey, I presented people with Control and Reckless. After reading Control, participants were asked if the following claim seems true or false.

- It would have been better if Connor's trip home hadn't led to an injury.

\footnotetext{
18 Thanks to Noah Lemos for suggesting this response. Putting my representative argument in terms of the variant yields this:

1. When someone deserves something, it's intrinsically better that she get it or there's a non-instrumental reason to give it to her.

2. Wrongdoers deserve things that are bad for them, e.g., suffering or punishment.

3. So, it's intrinsically better when wrongdoers get these things or there are non-instrumental reasons to give them these things.

19 Here's the reasoning. The variant view and the desert intuition jointly entail:

It's intrinsically better that Ricky sprained his ankle or there was a non-instrumental reason to make him sprain his ankle.
}

This and the reason intuition jointly entail:

It's intrinsically better that Ricky sprained his ankle.

This and the value intuition jointly entail the footnoted claim. 
Table 3 Responses: Study 3

\begin{tabular}{lcc}
\hline Response & Control & Reckless \\
\hline 1 & 1 & 6 \\
2 & 0 & 6 \\
3 & 1 & 2 \\
4 & 6 & 11 \\
5 & 2 & 10 \\
6 & 20 & 22 \\
7 & 81 & 54 \\
\hline
\end{tabular}

After reading Reckless, they were asked if the following claim seems true or false.

- It would have been better if Ricky's stunt hadn't led to an injury.

Recall, Connor was the Control agent, Ricky was the Reckless agent, and the cases stipulated that their injuries wouldn't have any good or bad consequences. To minimize order effects, I presented the case/question pairs randomly. Participants recorded their answers on the same Likert scale as above ( $1=$ almost definitely false, $7=$ almost definitely true).

I recruited 125 new participants via Amazon Mechanical Turk. People who took the previous surveys weren't allowed to take this one. I've reported 111 participants' responses. ${ }^{20}$ The results were as follows. Participants were statistically more likely to report an intuition that it would have been better if Connor hadn't been injured than they were to report this intuition about Ricky. But the vast majority still reported an intuition that it would have been better if Ricky hadn't been injured. Table 3 reports the number of participants who gave each response. ${ }^{21}$

Combined with the results of my earlier surveys, these results are evidence that there are widespread intuitions that are inconsistent with the above variant of the standard view. So, retributivists can't just endorse that view to avoid any problems that my earlier results might pose for them.

In the next section, I'll discuss the implications that my results have for retributivist arguments like the one sketched in Sect. 1. Much of my discussion will focus on the standard view, but everything that I say about it will also apply to the variant discussed in this section.

\footnotetext{
${ }^{20}$ I've excluded 14 participants' responses for the same reasons as in studies 1 and 2. Demographic data for the analyzed responses are: $54 \%$ male, $46 \%$ female, median age 31 . All were 18 years of age or older and in the US.

${ }^{21}$ I used Wilcoxon signed-rank tests to do the statistical analysis because the data was non-parametric. Here are the statistical details. 92.8\% reported an intuition that it would have been better if Connor hadn't been injured $(\mathrm{Mdn}=7$, Mean $=6.53$ ) and $77.5 \%$ reported an intuition that it would have been better if Ricky hadn't been injured ( $\mathrm{Mdn}=6$, Mean $=5.66, \mathrm{~T}=51, p<.001, \mathrm{r}=-.48)$.
} 


\section{Discussion}

My results are tentative evidence for the following claim: either the standard view is false or mistaken intuitions about desert are widespread. This poses an important challenge to retributivist arguments like the one sketched in Sect. 1. If the standard view is false, these arguments have a false premise. If mistaken intuitions about desert and its implications are widespread, some of the arguments' premises lack sufficient support. Recall that retributivists appeal to what they take to be widespread intuitions about desert to support their premises. If widespread intuitions about desert are mistaken, these intuitions can't obviously provide the requisite support. In this section, I'll consider several responses to this challenge.

The most obvious way that retributivists can respond to this challenge is by questioning the accuracy of my results. They might say that if I'd surveyed a larger and more diverse group of people, the vast majority might have reported intuitions that are consistent with the standard view. Retributivists might also take issue with how I framed Reckless. For example, they might say that I could have put more emphasis on how reckless Ricky was or on the care that he took to prevent harm to others. They might say that the vast majority of my participants-or of a larger and more diverse group - might have reported intuitions that are consistent with the standard view if I'd framed Reckless differently.

In response, I admit that different studies might yield different results. But the mere possibility of this doesn't license dismissing my challenge. ${ }^{22}$ If retributivists want to argue that my results are inaccurate, the best way to do that is to do more empirical work. If they do this and get different results, then they can try to argue that those results are more accurate than mine. In the absence of such work, my results should be taken seriously. So in the rest of the paper, I'll focus on other less speculative ways that retributivists might respond to my challenge.

Another way to respond to my challenge is by giving positive arguments for the standard view. This might cast doubt on intuitions that are inconsistent with it. I can't consider all such arguments here, so I'll just consider one of the most important. ${ }^{23}$ W.D. Ross compares two possible worlds that are identical save for one difference (2002: 58, 136-138). In the first world, the virtuous are deservedly happy and the vicious deservedly miserable. In the second, the virtuous are undeservedly miserable and the vicious undeservedly happy. Ross says that the first world is much better than the second. He takes this to show that the first world has some intrinsic goods that the second lacks. Specifically, he takes this to show that it's intrinsically good when the virtuous are deservedly happy and that it's intrinsically good when the vicious are deservedly miserable. He goes on to say that these values ground a prima facie duty of justice to distribute happiness and misery accordingly. If the desert bases and desert objects on which Ross focuses are representative of what

\footnotetext{
22 Regarding the diversity of my sample population, research suggests that the data obtained via Mechanical Turk is of comparable quality to that obtained by traditional recruitment methods in the social sciences. See Buhrmester et al. (2011).

23 Another argument defends the standard view by appealing to a fittingness analysis of desert. For critical discussion, see Berman (2013: 91, n 14) and Hanna (2013: 50-51).
} 
people can deserve and why, then his argument can be generalized to defend the standard view. $^{24}$

Many philosophers find arguments like Ross's compelling. ${ }^{25}$ But his argument fails. The apparent fact that the first world is better doesn't show that it's intrinsically good when the vicious are deservedly miserable. There's another possibility: rather than making the misery of the vicious good, desert might just make their misery less bad than the misery of the virtuous (cf. Hanna 2013: 46). The first world might be better because the misery in it isn't as bad as the misery in the second world. Given this possibility, the claim that the first world is better doesn't support Ross's conclusion. At best, that claim only shows that desert makes a normative difference. It doesn't tell us exactly what that difference is.

In response, retributivists could supplement Ross's argument somehow. Or they could respond to my challenge in another way. I'll consider three more replies along these lines.

The first reply says that retributivists don't have to appeal to desert and that they can justify punishment in other ways. It's tempting to say that this reply just misses my point, that I'm challenging desert-based arguments for punishment, and that my challenge stands even if there are other retributivist arguments for punishment. But dismissing the reply in this way would be too quick. Here's a more charitable way to take the reply. It concedes that desert-based arguments for punishment rely on questionable claims about desert. It just downplays the significance of this point. In effect, the reply says that my point isn't very significant because appealing to desert is just one way-perhaps not the best way-that retributivists can try to justify punishment. The problem with the reply, so understood, is that it misrepresents the significance of my point. Desert-based arguments for punishment are popular and their merits are hotly debated. Many retributivists endorse them and many anti-retributivists attack them. I've argued that these arguments might misunderstand the nature of desert. This is a significant point even if there are other and better retributivist justifications of punishment.

To sum up, the first reply to my challenge fails because it misrepresents the significance of my challenge. Consider the second reply, then. This reply defends the standard view by appealing to intuitions for it. Many philosophers take the view to be intuitively very compelling. Retributivists might say that we can be especially confident about these intuitions, confident enough to reject intuitions that are inconsistent with the standard view. They might even reformulate Ross's argument along these lines. The reformulated argument might go like this: Ross's first world is better; the standard view best explains why because the standard view is intuitively very compelling; so, the standard view is true.

\footnotetext{
${ }^{24}$ Here's one way to do that. Consider a world where the conscientious fare deservedly well and the reckless deservedly poorly. Compare this with a world where the conscientious fare undeservedly poorly and the reckless undeservedly well. The first world seems better. This suggests that Ross's argument can be put in terms of other desert objects. And it suggests that his argument can be reframed to cast doubt on the intuitions to which I've appealed.

${ }^{25}$ E.g., Berman (2013: 89), Hurka (2001: 7, 31), Kershnar (2000: 98-99), Pojman (1999: 291-292) and Zaibert (2017: 14-15).
} 
There at least two good reasons to doubt this reply. First, intuitions for the standard view don't obviously justify rejecting intuitions like the ones elicited by Reckless. Intuitions of the latter kind have explanatory value and my survey results suggest that they're widespread. So, they shouldn't be dismissed before considering the possibility that intuitions for the standard view are mistaken. The standard view may seem intuitively compelling largely because counterexamples to it and alternatives to it are easy to overlook. As a result, those who think more carefully about the view and potential counterexamples to it might find it much less compelling. They might even come to find it intuitively false, as I have.

Second, there's an independent reason to doubt the reliability of intuitions for the standard view: these intuitions seem especially likely to be fallible. The standard view is a very general view about desert. But desert claims and desert bases are remarkably diverse. ${ }^{26}$ Given this diversity, philosophers shouldn't uncritically accept intuitions for the standard view. They should carefully test these intuitions against intuitions about a sufficiently diverse set of cases first, including cases like Reckless. ${ }^{27}$ If philosophers ignore or dismiss intuitions about such cases, they risk overlooking important features of desert. Christopher Freiman and Shaun Nichols highlight this risk with an illuminating analogy between desert and grammar (2011: 131, 132). Intuitions about general grammatical principles can easily be mistaken because they aren't as sensitive to certain features of language that intuitions about particular sentences are. ${ }^{28}$ Freiman and Nichols plausibly suggest that intuitions about desert might be like this too.

To sum up, the second reply to my challenge doesn't obviously work either. It arguably overestimates the significance of intuitions for the standard view. And it arguably underestimates the significance of contrary intuitions. Consider the third and final reply to my challenge, then.

The third reply endorses another variant of the standard view. According to this variant, some but not all claims about what people deserve have the implications that the standard view says. Desert claims based on things like recklessly endangering oneself don't have these implications. But desert claims based on things like wrongdoing do because there's something special about these desert bases. An attractive feature of this reply is that it can accommodate the intuitions that most of my participants reported about both Reckless and Malicious.

The problem with this reply is simple: it's not obvious why anyone should think that only some claims about what people deserve have the relevant implications (cf. Berman 2013: 91, n 16, Hanna 2013: 51, 52). Retributivists who want to reply to my challenge by appealing to this view must argue for it. Otherwise, the reply will be ad hoc. I won't try to come up with arguments for this view here. I'll leave that to retributivists who find the view attractive.

\footnotetext{
${ }^{26}$ For illustration, see Feinberg (1970: 61-80), Kleinig (1973: 49-64), and Sher (1987: 6-8).

27 This isn't to suggest that intuitions about cases are decisive. Philosophers should reflect on them too and consider the possibility that they're mistaken.

28 Frieman and Nichols give an example: "competent speakers likely have the pre theoretical intuition that there is an abstract principle according to which a proper name has to come before any pronoun that is linked to it. But competent speakers also tend to have the pretheoretical intuition that the following sentence is well-formed: 'before he went to the dance, John greased his hair'” (2011: 131).
} 
Some retributivists might think that it's easy to defend the variant view, though. They might say that it's intuitively clear that desert claims based on things like wrongdoing have the requisite implications. And they might defend the variant view in familiar fashion: by appealing to intuitions about cases like Malicious. ${ }^{29}$ To see why this is a bad way to reply to my challenge, look again at the retributivist argument sketched in Sect. 1.

1. When someone deserves something, it's intrinsically good that she get it or there's a non-instrumental reason to give it to her.

2. Wrongdoers deserve things that are bad for them, e.g., suffering or punishment.

3. So, it's intrinsically good when wrongdoers get these things or there are noninstrumental reasons to give them these things.

I've challenged premise 1 . Suppose that retributivists respond by replacing it with a narrower claim about the normativity of desert based on wrongdoing. For example:

When a wrongdoer deserves something bad for her because of her wrongdoing, it's intrinsically good that she get it or there's a non-instrumental reason to give it to her.

And suppose that retributivists defend this new premise by appealing to case-based intuitions about desert, value, and reasons. That is, suppose they defend the premise by appealing to intuitions like these: it's intrinsically good when agents like Mal get the harms that they deserve in virtue of their wrongdoing and there are noninstrumental reasons to give them these harms. There's an obvious problem here: the new argument is circular. It defends the new premise by appealing to certain case-based intuitions and it uses that premise to defend the very same intuitions. Unlike the retributivist argument sketched at the beginning of Sect. 1, the new argument doesn't actually give any independent support for those intuitions. So, it fails.

\section{Conclusion}

I conclude that my challenge to retributivist arguments that appeal to desert is worth taking seriously. Retributivists who want to meet this challenge have several options worth exploring. One option is to investigate people's intuitions about desert, value, and reasons in more detail. Further research might show that the problematic intuitions that I've elicited are less widespread than my results suggest. Or it might highlight special reasons to doubt these intuitions. Another option is to come up with better arguments for the standard view or for other retributivist-friendly views about desert's normativity.

29 Thanks to Hailey Huget for this reply. 
One option is ruled out, though: retributivists can't continue to just assume that desert works in the way that they need it to. They-and philosophers of punishment more generally-must think more carefully about the normativity of desert. ${ }^{30}$

\section{References}

Alexander, L., and Ferzan, K.K. (2009). (with S. Morse), Crime and Culpability: A Theory of Criminal Law, New York: Cambridge University Press.

Berman, M. (2008). "Punishment and Justification”, Ethics 118(2): 258-290.

Berman, M. (2013). "Rehabilitating Retributivism", Law and Philosophy 32(1): 83-108.

Boonin, D. (2008). The Problem of Punishment, New York: Cambridge University Press.

Buhrmester, M., Kwang, T., and Gosling, S.D. (2011). “Amazon's Mechanical Turk: A New Source of Inexpensive, Yet High-Quality, Data?”, Perspectives on Psychological Science 6(1): 3-5.

Davis, L. (1972). "They Deserve to Suffer", Analysis 32(4): 136-140.

Ezorsky, G. (1972). "The Ethics of Punishment", in her Philosophical Perspectives on Punishment, Albany: State University of New York Press.

Feinberg, J. (1970). "Justice and Personal Desert", in his Doing and Deserving, Princeton, NJ: Princeton University Press.

Feldman, F. (2016). Distributive Justice: Getting What We Deserve from Our Country, New York: Oxford University Press.

Feldman, F. and Skow, B. (2015). "Desert", The Stanford Encyclopedia of Philosophy (Winter 2016 Edition), Edward N. Zalta (ed.), URL =<https://plato.stanford.edu/archives/win2016/entries/desert/>.

Fischer, J.M. (2006). "Punishment and Desert: A Reply to Dolinko", Ethics 117(1): 109-118.

Fischer, J.M. (2013). "Desert and the Justification of Punishment", in T.A. Nadelhoffer (ed.), The Future of Punishment, New York: Oxford University Press.

Freiman, C., and Nichols, S. (2011). "Is Desert in the Details?", Philosophy and Phenomenological Research 82(1): 121-133.

Greene, J. (2008). "The Secret Joke of Kant's Soul", in W. Sinnott-Armstrong (ed.), Moral Psychology, vol. 3, Cambridge, MA: MIT Press.

Greene, J., and Cohen J. (2004). "For the Law, Neuroscience Changes Nothing and Everything", Philosophical Transactions of the Royal Society B - Biological Sciences 359(1451): 1775-1785.

Hanna, N. (2013). "Two Claims about Desert", Pacific Philosophical Quarterly 94(1): 41-56.

Hanna, N. (2014). "Retributivism Revisited", Philosophical Studies 167(2): 473-484.

Hurka, T. (2001). "The Common Structure of Virtue and Desert", Ethics 112(1): 6-31.

Husak, D. (2000). "Holistic Retributivism", California Law Review 88(3): 991-1000.

Husak, D. (2013). "Retributivism In Extremis", Law and Philosophy 32(1): 3-31.

Kagan, S. (2003). "Comparative Desert", in S. Olsaretti (ed.), Desert and Justice, New York: Oxford University Press.

Kelly, E. (2009). "Criminal Justice without Retribution", Journal of Philosophy 106(8): 440-462.

Kershnar, S. (2000). "A Defense of Retributivism", International Journal of Applied Philosophy 14(1): $97-117$.

Kershnar, S. (2001). Desert, Retribution, and Torture, Lanham, MD: University Press of America.

Kleinig, J. (1973). Punishment and Desert, The Hague: Martinus Nijhoff.

Moore, M. (1987). "The Moral Worth of Retribution", in F. Schoeman (ed.), Responsibility, Character, and the Emotions, New York: Cambridge University Press.

\footnotetext{
${ }^{30}$ Thanks to audiences at the College of William \& Mary, Drexel University, the 6th UK Experimental Philosophy Group Conference at the University of Nottingham, the 8th Rocky Mountain Ethics Conference at CU Boulder, the 2015 Buffalo Experimental Philosophy Conference, the 3rd Annual Philosophers Cocoon Philosophy Conference at the University of Tampa, and the 2016 Pacific APA. Thanks also to several anonymous referees and to Hailey Huget, Kyle Scott, and Ariela Tubert, my commentators at RoME, PCPC, and the APA respectively.
} 
Moore, M. (1993). “Justifying Retributivism”, Israel Law Review 27(1-2): 15-49, reprinted in M. Moore, Placing Blame, New York: Oxford University Press.

Narveson, J. (1974). "Three Analysis Retributivists", Analysis 34(6): 185-193.

Olsaretti, S. (2003). "Debating Desert and Justice", in S. Olsaretti (ed.), Desert and Justice, New York: Oxford University Press.

Parfit, D. (2011). On What Matters, New York: Oxford University Press.

Pereboom, D. (2013). "Free Will Skepticism and Criminal Punishment", in T.A. Nadelhoffer (ed.), The Future of Punishment, New York: Oxford University Press.

Pojman, L.P. (1999). "Does Equality Trump Desert?", in L.P. Pojman and O. McLeod (eds.), What Do We Deserve?, New York: Oxford University Press.

Rosen, G. (2002). "Culpability and Ignorance", Proceedings of the Aristotelian Society 103(1): 61-84.

Ross, W.D. (2002). The Right and the Good, New York: Oxford University Press.

Sher, G. (1987). Desert, Princeton: Princeton University Press.

Tadros, V. (2011). The Ends of Harm, New York: Oxford University Press.

Vilhauer, B. (2009). "Free Will and Reasonable Doubt", American Philosophical Quarterly 46(2): $131-140$.

Wiegman, I. (2017). “The Evolution of Retribution: Intuitions Undermined”, Pacific Philosophical Quarterly 98(2): 193-218.

Zaibert, L. (2006). Punishment and Retribution, Aldershot: Ashgate.

Zaibert, L. (2017). "On the Matter of Suffering: Derek Parfit and the Possibility of Deserved Punishment", Criminal Law and Philosophy 11(1): 1-18.

Zimmerman, M.J. (1997). "Moral Responsibility and Ignorance", Ethics 107(3): 410-426.

Zimmerman, M.J. (2002). “Controlling Ignorance: A Bitter Truth”, Journal of Social Philosophy 33(3): 483-490. 